\title{
OR1G1 wt Allele
}

National Cancer Institute

\section{Source}

National Cancer Institute. OR1G1 wt Allele. NCI Thesaurus. Code C51717.

Human OR1G1 wild-type allele is located in the vicinity of $17 \mathrm{p} 13.3$ and is approximately 1 $\mathrm{kb}$ in length. This allele, which encodes olfactory receptor 1G1 protein, is involved in neuronal responses and olfactory perception. 